Zukalová, H. (2011). ICT v terciárním vzdělávání pohledem studentů. In T. Janík, P. Knecht, \& S. Šebestová (Eds.), Smišený design v pedagogickém výzkumu: Sbornik př́spěvki̊ z 19. výroční konference České asociace pedagogického výzkumu (s. 494-499). Brno: Masarykova univerzita.

Dostupné z: http://www.ped.muni.cz/capv2011/sbornikprispevku/zukalova.pdf doi: 10.5817/PdF.P210-CAPV-2012-89

\title{
ICT v terciárním vzdělávání pohledem studentů ${ }^{1}$
}

\author{
ICT in tertiary education from the students' point of view
}

\author{
Hana Zukalová
}

\begin{abstract}
Abstrakt: Př́íspěvek je zaměřen na vstup technologií do chodu vysoké školy očima studentů. V první části př́spěvku jsou představena některá teoretická východiska a především je poukázáno na nutnost uvažovat o problematice komplexním a holistickým způsobem. Empirická část přináší první výsledky kvalitativního šetření. Klíčové se v tuto chvíli ukazují hodnoty studentů, konkrétně postava charismatického učitele a „živé slovo“. Tyto hodnoty ovlivňují další postoje k technologiím a jsou respektovány v príípadě, že nepředstavují jejich ohrožení.
\end{abstract}

Klíčová slova: terciární vzdělávání, e-learning, ICT, EICT

\begin{abstract}
This contribution deals with the implementation of technologies into higher education institutions from the students' point of view. In the first part of my contribution I focus on the theoretical background and I point out, it is necessary think about this phenomenon in complex a holistic way. In the empirical part I introduce the first results of my qualitative research. In this stage of research, values seem to be crucial, specifically charismatic personality of teacher and „lived word“. This values influence the others attitudes to EICT and the EICT is accepted as a tool that should not affect negatively the key values of education.
\end{abstract}

Keywords: tertiary education, e-learning, ICT, EICT

\section{1 Úvod}

Vysoké školy zavádí technologie do výuky i do svého chodu již poměrně dlouhou dobu. Jaké jsou důsledky a efekty této implementace? Zvyšuje se efektivita výuky a mají technologie pozitivní dopad na výsledky studentů, nebo nastává tzv. produktivní paradox ve vysokoškolském vzdělání? Definování produktivního paradoxu se připisuje Robertu Sollowovi, který již v roce 1987 popsal rozpor mezi investicemi do ICT a hodnotou výstupů v ekonomice. Youssef a Ragni (2008) aplikovali tento paradox ve svém článku na vysokoškolské vzdělání a ukazují, že zatímco investice do technologických inovací ve vzdělávání vzrůstají, produktivita vzdělávání ve většině evropských zemí klesá. Výzkumy zaměřené přímo na vliv ICT na úspěšnost studentů mají často protichůdné výsledky. Některé ukazují pozitivní vliv na výkon studentů, některé pouze malý či záporný dopad na výsledky studentů (srov. Youssef \& Ragni, 2008). Toto zjištění mě přivádí k výchozí tezi mého uvažování, namísto měření a srovnávání investic do materiálního vybavení

${ }^{1}$ Projekt byl podpořen GA ČR: Škola: výzkum vnitřních procesů a vnějších podmínek jejího fungování (GD406/09/H040) a grantem děkana Filozofické fakulty. Autorka děkuje za poskytnutou podporu. 
je zapotřebí uvažovat o kvalitativní stránce vstupu ICT do vzdělávání v rámci konkrétních jednotlivých univerzit různých oborů a zaměření. $V$ této práci mě především zajímá, jak tuto implementaci vnímají studenti jako klíčový aktéři vzdělávacího procesu. $V$ teoretické cásti práce představím některé současné proudy uvažování o ICT ve vzdělávání, empirická část přináší první výsledky mého výzkumu, který je zaměřen na pohled studentů a jejich reflexi implementace ICT do vzdělávání na Masarykově univerzitě Filozofické fakultě v Brně.

\section{Ekologické uvažování o e-learningu}

Ellis a Goodyear (2010) přichází s „ekologickým“ pojetím uvažování o e-learningu ve vysokoškolském vzdělávání. Hovoří o tzv. ekologii trvale udržitelných inovací. Termín ekologie vyjadřuje vzájemnou propojenost a závislost všech částí systému, v tomto prípadě vysoké školy. Použití termínu ekologie není nové, např. již v roce 1996 Hannafin a Hannafin (in Ellis \& Goodyear, 2010) využili metaforu ekologie a ekosystému jako cestu k vystihnutí komplexnosti a vzájemné závislosti mnoha prvků a aktivit, které směřují k úspěšnému vzdělávacímu prostředí. Jejich ekologické pojetí se vyvíjí směrem od paradigmatu „porovnat a nahradit“, které staví ICT do role „vyzývatele“, který chce nahradit vše staré. O celistvosti jako východisku pro zkoumání pedagogických otázek hovoří autoři Pol et al. (2006) ve své studii věnující se kultuře školy. Mimo jiné uvádí: „Kultura školy je celistvým pojmem, který spojuje jednotlivé oblasti fungování školy. Celistvost se pak stává východiskem řešení mnoha pedagogických otázek souvisejících především se zkvalitňováním práce školy.“ (s. 7) Hloušková (2008) definuje kulturu školy následovně:

Kulturu školy vytvářejí jednotliví aktéři školního života (učitelé, ředitelé, žáci, rodiče a další) na základě svých osobních zkušeností. Zahrnuje jejich společné hodnoty, postoje, představy, normy (případně etický kodex), přesvědčení, názory, a tím získává normativní funkci ve vztahu ke každodennímu chodu školy. Projevuje se v symbolech, rituálech, zvycích, př́ibězích, preferovaném chování, vlastní výchovné a vzdělávací práci i v klimatu školy. (s. 40)

\section{Výuka v novém hávu nebo nová záplata do starých šatů?}

Vstup technologií př́mo do výuky je důležitou oblastí mého zájmu. Jak uvádí Alan Lesgold: „Počítač je jako zesilovač. Umocňuje ty nejlepší výukové metody i ty nejhorší. Je zde reálné nebezpečí, že ty horší mohou převážit, a omezit tak schopnosti budoucích dospělých.“ (in Brdička, 2009). Youssef a Ragni (2008) zdůrazňují, že „staré metody potřebují staré vzdělávací technologie, nové technologie potřebují nové organizační inovace“ (s. 51). Jinými slovy, pokud implementujeme ICT do výuky, ale všechny další podmínky a okolnosti zůstanou stejné, je možné, že technologie vytvoří cizorodou subkulturu a vzdělávací potenciál nebude využit. Tuto úvahu považuji za klíčovou pro další uvažování. Roblyer (2006) podotýká, že pedagogové mají tendenci uvažovat o vzdělávacích nebo instruktážních technologiích jako o zařízení. Jak ale uvádí Muffoletto (1994, in Roblyer, 2006), technologie nejsou sbírka strojů and zařízení, ale způsob jednání.

Jde tedy především o přijetí technologií, které se stávají součástí výuky a procesu učení. $\mathrm{Z}$ toho důvodu dále rozlišuji technologie, jejichž využití nese vzdělávací potenciál zkratkou $E I C T^{2}$, kterou ve své práci použil Youssef a Ragni (2008) a pod zkratkou ICT rozumím technologie, které jsou využívány ve vzdělávání, ale za jiným než vzdělávacím účelem (např. administrativa).

2 educational information and communication technologies 
Podobně Zounek (2009) se zamýšlí nad termínem e-learning. Hlásku $e$ vnímá jako vztahující se k vlastním prostředkům a nástrojům, learning tedy učení jako klíčový proces a stěžejní pojem pedagogiky. Zajímavá je úvaha o spojovníku mezi e a learning, který může symbolizovat spojení technického nástroje a principů učení. (Zounek, 2009).

\section{Metodologie empirického výzkumu}

V empirické části práce se soustředím na otázku, do jakých oblastí chodu vysoké školy významně vstoupily technologie optikou studentů. Vzhledem k tomu, že jde o dosud ne príliš probádané téma, jde mi v první fázi především o identifikaci důležitých oblastí, které se ve výpovědích respondentů objeví. Z toho důvodu jsem zvolila kvalitativní výzkumnou metodologii, jejíž podstata umožňuje poznání široce definovaného jevu. Respondenty jsou studenti posledních ročníků Masarykovy univerzity Filozofické fakulty v Brně. V současné době jsem provedla rozhovory se čtyřmi studenty a analyzovala pomocí softwaru ATLAS ti.

Cílem výzkumu je identifikace významných oblastí školy, do kterých vstupují technologie pohledem studentů. Sledována je kauzalita s celkovým edukačním prostředím a kulturou školy. Nejde o postihnutí všech elementů kultury školy, ale těch, které se ve výpovědích respondentů ukáží jako významné. Soustředila jsem se také na vztah EICT a učebního procesu. Výzkumná otázka zní: „Do jakých oblastí kultury (chodu) vysoké školy významně vstupují technologie pohledem studentů?“"

\section{Vyložení karet}

V realizovaných rozhovorech jsem identifikovala čtyři kategorie, které se jeví v postojích studentů k technologiím ve vzdělání jako klíčové (viz obrázek 1). Pomocí techniky vyložení karet nyní jednotlivé kategorie stručně interpretuji.

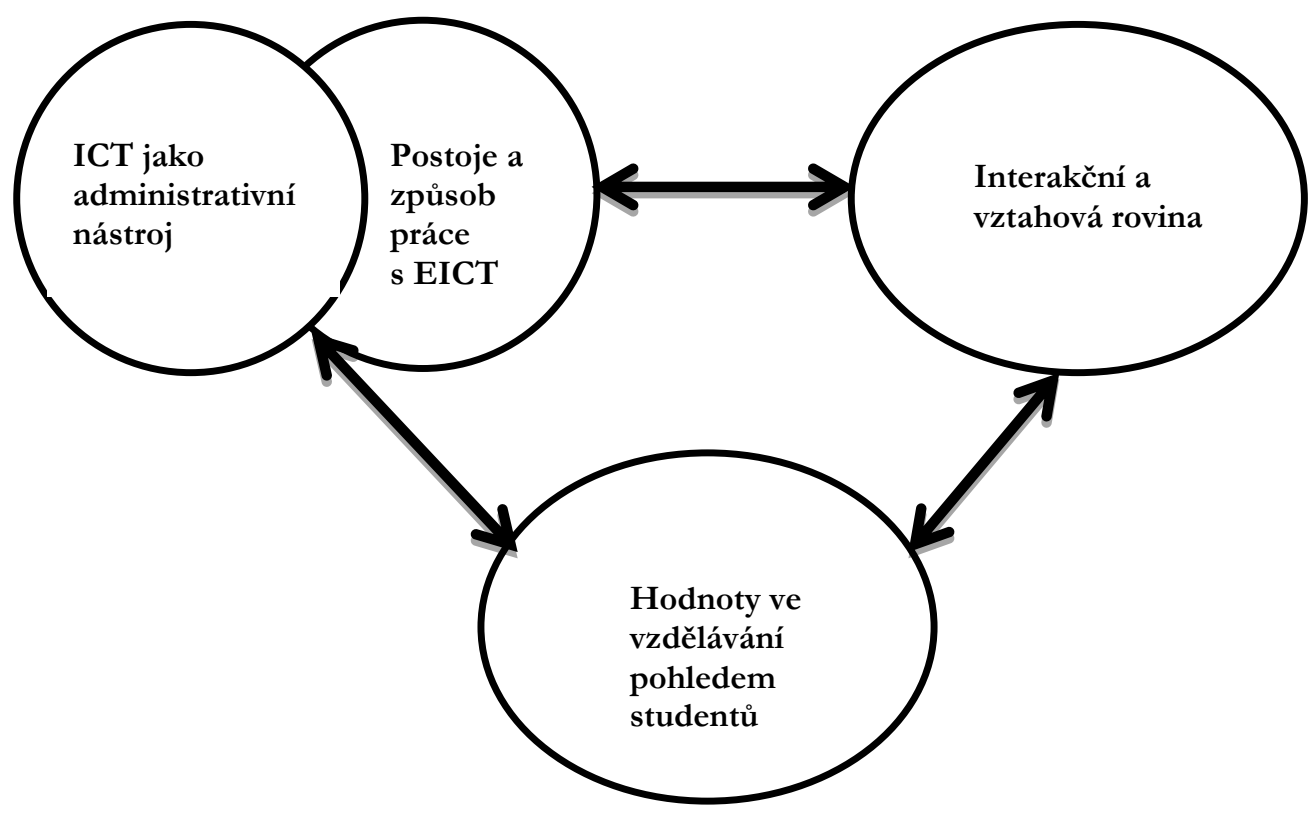


Obrázek 1. Vzájemné spojení identifikovaných kategorií.

\subsection{Základni hodnoty ve vzdělávání očima studentů}

Respondenti výzkumu jsou zastánci především tradičních hodnot ve vzdělávání. Klíčová je pro ně charismatická osobnost učitele. Osobnost, která je nositelem široké palety znalostí a dokáže zaujmout a tyto znalosti předávat. S tím je úzce spojena další klíčová hodnota, a to „živé slovo“. Využivání technologií může představovat ohrožení těchto hodnot, v takovém př́padě jejich využívání není akceptováno. Studenti pocitují především nedostatek živého slova. Příčinu spatřují v masifikaci vzdělávání a využívání ICT chápou jako nezbytný důsledek tohoto procesu. Respondent Jiří k tomu říká: „Když je tam 100 lidí, tak už to prostě nejde, je to taková masa, ale není tam to, že někomu něco predáš“. Hodnoty, které studenti ve vzdělávání zastávají, jsou zásadním prvkem při vytváření postojů k EICT.

\subsection{Postoje studentů k EICT}

Zatím lze konstatovat, že respondenti využívají pouze základní možnosti a nástroje EICT (textový editor, vyhledávání informací a moodle) a přímo ve výuce se setkávají s EICT zř́ídka. Anna: „Pamatuju si jeden jediný predmět tak, že by každý seděl u počitače, víš, nepočítám, že by ten učitel seděl u počitače a něco pro nás promítal“. Respondent Pavel: ,, To je asi tak 5 \% lidí co použivá Elf nebo odpovédníky. Jsou to většinou mladši vyučujicí“. Toto zjištění kontrastuje s technologickými možnostmi fakulty. Nabízí se interpretace, že klíčoví aktéři vzdělávacího procesu dosud nerozpoznali plně možnosti a šíri vzdělávacího potenciálu technologií. Vzhledem $\mathrm{k}$ počtu respondentů není možné zjištění zobecnit, otevírá ale půdu pro další zkoumání. Studenti neodmítají při vzdělávání využití technologií, nesmí se ale stát něčím, co ohrožuje jejich základní hodnoty, technologie by měly zůstat „, v jejich službách“.

\subsection{ICT jako administrativní nástroj}

Studenti ICT plně akceptují při využívání v administrativní „,manažerské“ rovině. Tento způsob práce s ICT je pro ně zároveň i nejčastější a nejvíce intenzivní. Využívání univerzitního informačního systému se může ale stát zdrojem frustrace. Anna řeší různé problémy v průběhu celého studia, na začátku dokonce kvůli školnímu informačnímu systému pochybovala o možnosti zvládnout své studium. Často je i zdrojem vážnějších studijních obtíží, kupř́ikladu studentka Lenka kvůli nedostatkům v informačním systému prodlužovala studium. Přesto je technologie v tomto př́ípadě akceptována jako nezbytnost či slovy Anny jako nutné zlo: ,já jako laik to beru jako nutné zlo, se kterým je potřeba se nějak vyrovnat".

\subsection{Interakční a vztahová rovina}

I v tomto př́ípadě se potvrdilo, že pro studenty představují technologie především administrativní nástroj. V komunikaci s vyučujícími řeší především organizační záležitosti. Ukázalo se zde zajímavé zjištění, studenti akceptují, pokud charismatický vyučující nepoužívá e-mail, oslovení touto cestou může být $\mathrm{v}$ některých prrípadech chápáno téměř jako nezdvořilost. Jiří: „, Tím mailem mi to přijde skoro až takové, třeba na té historii mi to přijde až neslušné. " Studenti si tedy vytváŕí jakési návody k použití: „Takhle, já už po těch letech vím, že aby člověk zvládl vše, jak má, musí vědět spoustu informací kolem. Vědět, jak někteři lidé třeba pracují, jací jsou a tudiž vědět, že profesor ten a ten nepouživá internet a tudiž se tomu přizpůsobit. "(Anna).

Technologie jsou využívány i ke vzájemné komunikaci mezi studenty, opět ale spíše v rovině organizační nikoliv vzdělávací. Respondenti jednak nemají prŕliš představu o dostupných 
komunikačních platformách, někteří virtuální diskuze př́mo odmítají. Cituji Jiř́ího: „A to nejde přece poslat nějakým mailem, nebo chatem, nebo smskou, ale to musí se predat osobně v tom rozhovoru. Předávaji se gesta, předávají se rituály, to prostě nejde napsat, jako by to byl prostě úpadek. Bylo živé slovo, pak byla litera a ted’ je mail a já nevím, až se to degraduje na sms, tak bude konec světa."

\section{Závěr}

Chceme-li poznat jednu část systému, musíme ji sledovat jako součást celku, která je ve vzájemné interakci a spojení $\mathrm{s}$ dalšími částmi. Takto široce nastavené výzkumné pole nám umožní vysledovat vzájemnou kauzalitu jednotlivých prvků, které je poté možné zkoumat v detailech. V tuto chvíli se jako klíčové kategorie ukázaly hodnoty a vztahová rovina. Respondenti mého výzkumu jsou zastánci tradičních hodnot, identifikovala jsem v tuto chvíli klíčový význam charismatického učitele a ,„̌ivého slova“. Technologie nesmí představovat ohrožení těchto hodnot, ale musí být $v$ jejich službách. Pro úspěšnou implementaci do univerzitního systému a učebního procesu by měly být tyto hodnoty rozpoznány, vzájemně se podporovat a nevytvářet protichůdné tenze. Na základě dosavadní analýzy lze konstatovat, že technologie do prostředí Filozofické fakulty v Brně byly dobře integrovány na administrativní „manažerské“ rovině, jejich vzdělávací potenciál ale nebyl v očích studentů dosud rozpoznán a využit. Lze zhodnotit, že respondenti využívají pouze základní nástroje a možnosti EICT. Studenti akceptují, že vyučující nepracují s technologiemi ve výuce, nemají ani představuju, jaké možnosti EICT nabízí. V této fázi výzkumu není možné výsledky zobecnit, vzájemná závislost hodnot studentů a postojů k EICT se ale zdá být zřetelná.

\section{Literatura}

Brdička, B. (2009). Difuze technologií ve škole 21. století. Spomocník.cz. Dostupné z www.spomocnik.cz. Ellis, A. R., \& Goodyear, P. (2010). Students' experiences of e-learning in higher education. New York: Routledge.

Hloušková, L. (2008). Proměna kultury školy v pedagogických diskurzech. Brno: MU v Brně.

Pol, M., Hloušková, L., Novotný, P., \& Zounek, J. (Eds.). (2006). Kultura školy. Př́spěvek k výzkumu a rozvoji. Brno: MU v Brně.

Roblyer, M. (2005). Integrating educational technology into teaching. New Jersey: Prantice hall.

Youssef, B., A., \& Dahmani, M. (2008). The impact of ICT's on students' performance in higher education: Direct effects, indirect effects and organizational change. University and Knowledge Society Journal, 5(1), 45-56.

Youssef, B., A., \& Ragni, L. (2008). Uses of educational information and communication technologies: From digital divides to digital trajectories. University and Knowledge Society Journal, 5(1), 70-82.

Zounek, J. (2009). E-learning - jedna z podob učení v moderní společnosti. Brno: MU v Brně.

\section{Kontakt}

Mgr. Hana Zukalová

Masarykova Univerzita

Filozofická fakulta, Ústav pedagogických věd

A. Nováka 1, 60200 Brno

e-mail: hanna@mail.muni.cz 


\section{Bibliografické údaje}

Zukalová, H. (2011). ICT v terciárním vzdělávání pohledem studentů. In T. Janík, P. Knecht, \& S. Šebestová (Eds.), Smišsený design v pedagogickém výzkumu: Sborník přispěvků z 19. výroční konference České asociace pedagogického výzkumu (s. 494-499). Brno: Masarykova univerzita.

Dostupné z: http://www.ped.muni.cz/capv2011/sbornikprispevku/zukalova.pdf doi: 10.5817/PdF.P210-CAPV-2012-89 